Miami Nature Biotechnology Short Reports

TheScientificWorld (2001) 1(S3), 40SR

ISSN 1532-2246; DOI 10.1100/tsw.2001.145

\title{
REGULATION OF T-CELL APOPTOSIS BY SEQUENCES ENCODED AT THE LUCA- 15 CANDIDATE TUMOUR SUPPRESSOR LOCUS
}

Mirna Mourtada-Maarabouni*(1), Leslie C. Sutherland (1), Jeremy P. Clark (2), Colin S. Cooper (2) and Gwyn T. Williams (1)

(1)School of Life Sciences, Keele University, Staffordshire, U.K. ST5 5BG. (2)Molecular Carcinogenesis, Haddow Labs, Institute of Cancer Research, Sutton, SMG2 5NG

*m.mourtada@biol.keele.ac.uk

INTRODUCTION. Using an episomal retrieval functional expression cloning system(1), a 431 bp fragment of cDNA (je2 ) was identified, which strongly inhibited Fas-mediated apoptosis in Jurkat human T-cells(2). Je2 maps to the LUCA22 human locus at 3p21.3, a highly significant lung cancer tumour suppressor locus (2), and lies in the antisense orientation within an intron of Luca-15 gene. We have investigated the effect of Je2 on apoptosis in another human T-cell line CEM-C7 and using DNA microarrays, we report the alteration of the expression of several genes by Je2.

METHODS. Je2 was subcloned into pcDNA3 and was introduced into CEM-C7 cells by electroporation. Stable clones were exposed to $5 \mathrm{ng} / \mathrm{ml}$ anti-Fas for $24 \mathrm{~h}$, after that time, cell viability was determined by vital dye staining. Details for the sample preparation and microarray processing will be described elsewhere. Fold changes in gene expression were determined by using GenePix 2 software.

RESULTS. Stable expression of the antisense je2 sequence produced marked inhibition of Fas-mediated apoptosis (Fig.1). Je2 transfected clones maintained the ability to proliferate in the continuous presence of anti-Fas, and were also protected from apoptosis induced by other stimuli (not shown).

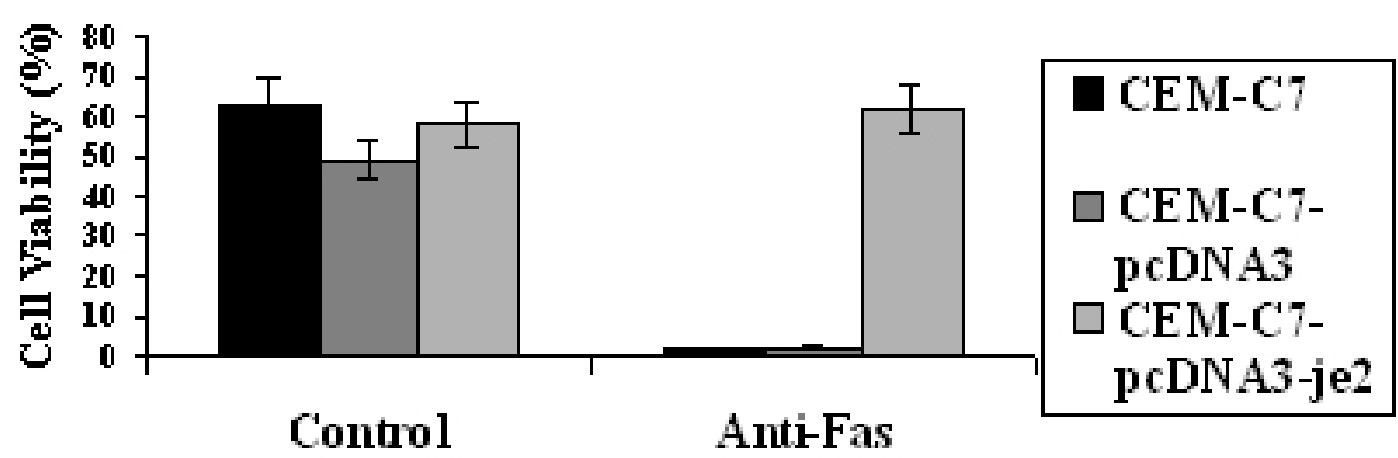


In addition, stable expression of je2 altered the expression of several genes, some of these genes were previously reported to regulate apoptosis. Some of the genes that were differentially expressed are listed in Table 1.

\begin{tabular}{|c|c|c|}
\hline W & Fold & Entrez definition \\
\hline Genes down-regulated & & \\
\hline 241481 & 5 & Casp ase-10 \\
\hline 724831 & 6 & B-cell lymphom a protein $7 \mathrm{~B}$ \\
\hline 509641 & 15 & Interfer on- inducible protein \\
\hline 712840 & 17 & Transcription factor Stat5b \\
\hline Genes up-r egulated & & \\
\hline 213136 & 12 & B-cell tran slocation gene 2 (BTG2) \\
\hline 813630 & 7 & Pim-1-on cogene \\
\hline 221846 & 5 & Checkpoint suppressor l- mRNA \\
\hline
\end{tabular}

DISCUSSION. Sequence homology searches revealed that je2 maps to 3p21.3, to an intronic region of LUCA-15. Northern blotting studies have revealed clear evidence for alternative splicing of the LUCA-15 gene transcripts (2). Over-expression of a splice variant of LUCA-15, clone 26, is reported to inhibit cell proliferation and sensitise the cells to Fas-mediated apoptosis (2). It is therefore attractive to speculate that like other apoptosis regulators, different transcripts of LUCA-15 together encode both inducers and suppressors of apoptosis. Our observation suggests that je2 function to suppress cell death and indicates that LUCA-15 can regulate the core mechanism of apoptosis.

ACKNOWLEDGEMENT. This work was supported by the Wellcome Trust.

\section{REFERENCES.}

1. $\quad$ Yates, J., Warren, N., and Sudgen, B. (1985) Nature 313, 812-815

2. $\quad$ Sutherland, L.C., Gill, S.E., Cable, H.C., Poirier, G.G., Miller, B.A., Cooper, C.S., and Williams, G.T. (2000) Oncogenes 35(19), 3774-3778 

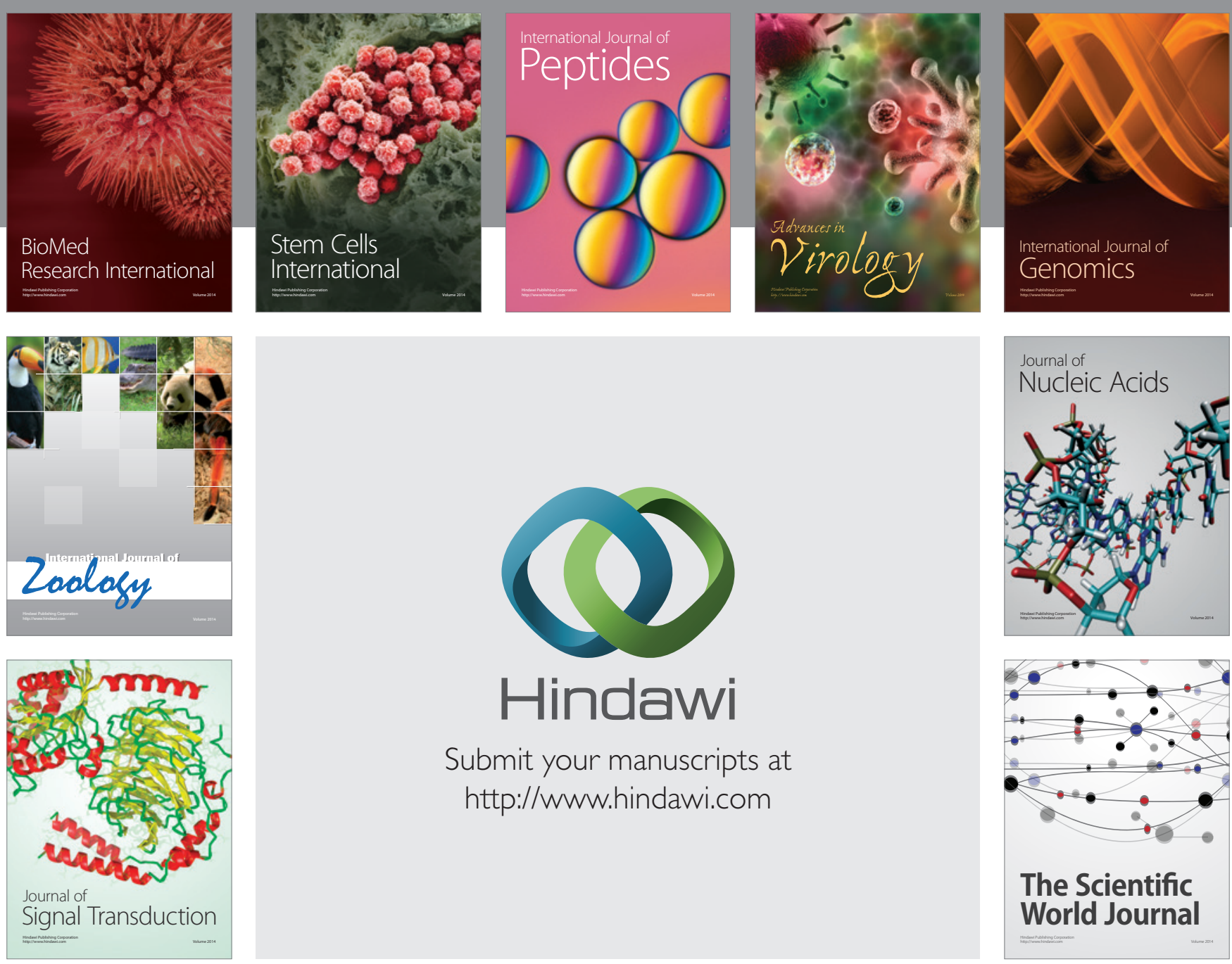

Submit your manuscripts at

http://www.hindawi.com
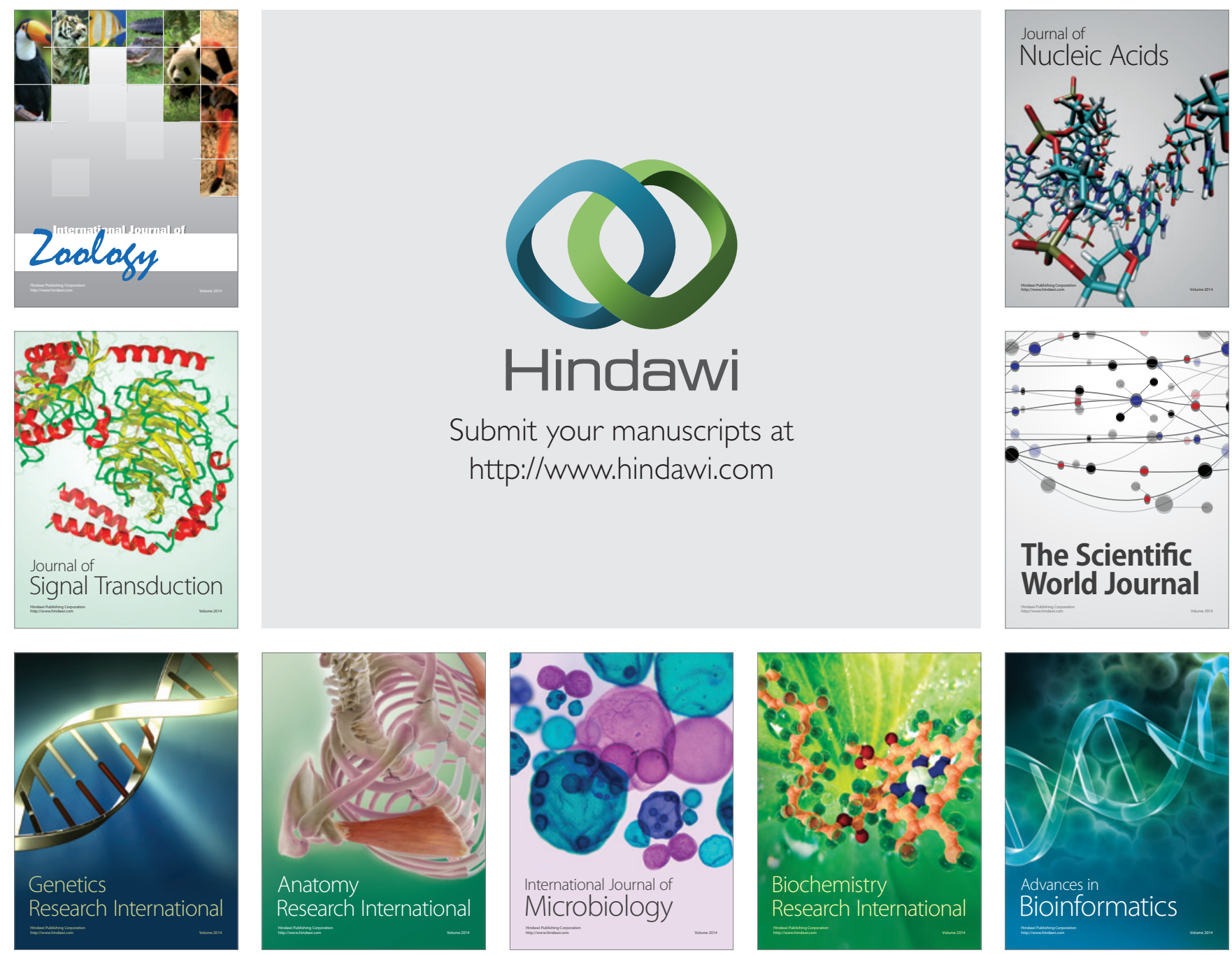

The Scientific World Journal
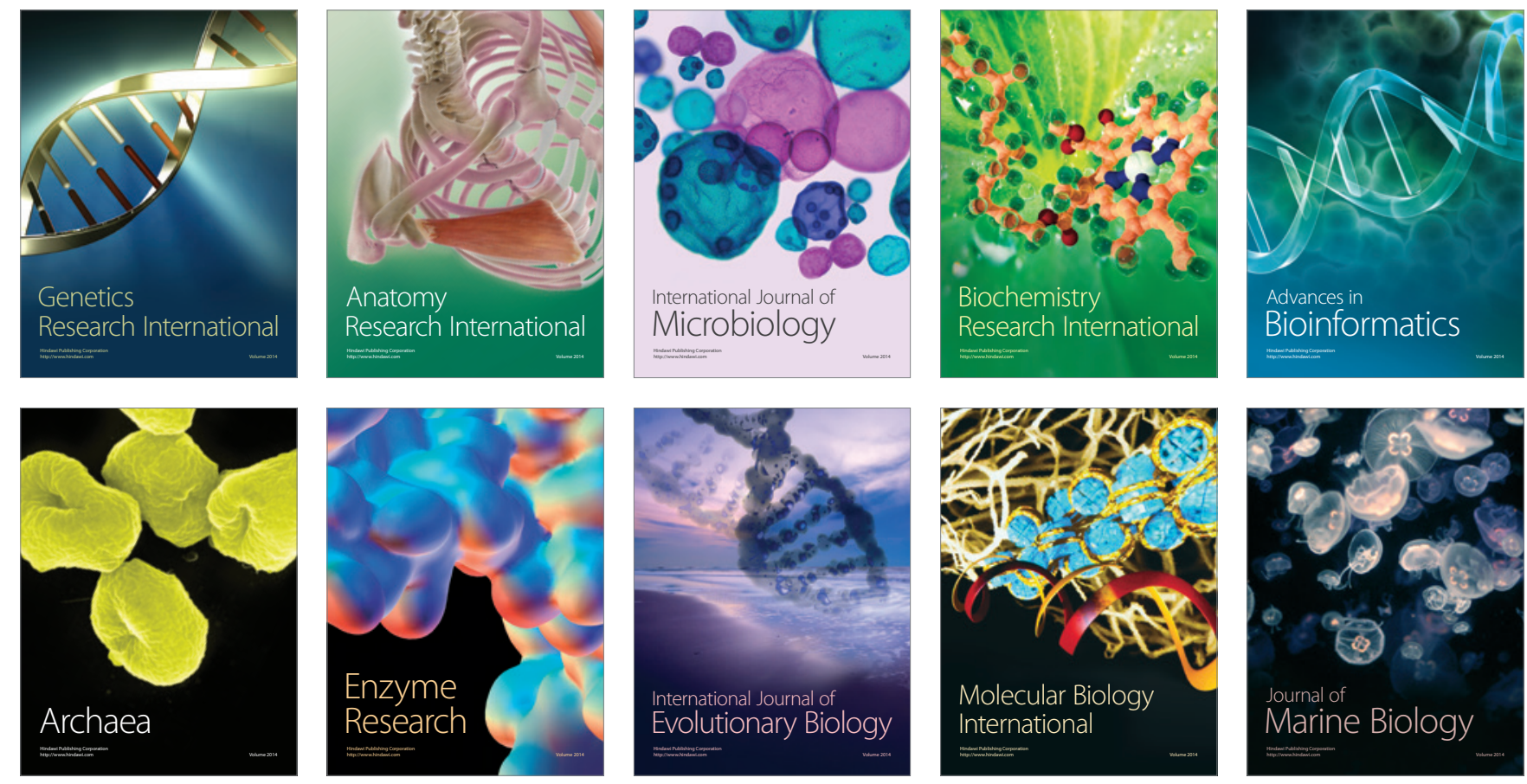